\title{
Tax morale, Occupation and Income Level: An Analysis of Portuguese Taxpayers
}

\author{
C. Sá, A. Martins, and C. Gomes
}

\begin{abstract}
Tax morale is recognized as one of the most important variables to understand the levels of compliance obtained in most countries. This paper analyzes the impact of occupational status, income level, behavioral, political and psychological factors on tax morale level of Portuguese taxpayers. A sample of 1,514 Portuguese individuals was obtained from the European Values Study (EVS) developed in 2008. A factor analysis was used to extract the underlying dimensions of tax morale. Multiple regression analysis was used to explore the relationship between the dimensions revealed by factor analysis, occupational status, income level, and tax morale. The findings suggest that occupational status, income, political democratic system, individual satisfaction, trust in others, and individual's identification with Portugal have a strong significantly effect on tax morale.
\end{abstract}

Index Terms-Portugal, tax morale, tax compliance.

\section{INTRODUCTION}

The challenge faced by governments to simultaneously obtain high levels of fiscal revenues, promote national economic growth, country's competitiveness and maintains an equitable tax system renewed research interest on tax compliance. Recent research recognizes tax morale as the key to explain the levels of compliance obtained in most countries [1]. Tax morale is understood as the intrinsic motivation to comply with fiscal duties [2]. Empirical studies found strong evidence of a negative correlation between tax morale and tax evasion and between tax morale and the size of shadow economy [1], [3]. A better understanding on individual heterogeneity in tax morale may contribute for the development of alternative mechanisms to reduce tax evasion and to improve tax compliance. Such knowledge is of particular importance because of the negative consequences that tax evasion has on public revenues, and on equity level of the tax system [4].

Based on literature review we identified a set of socio-economic, behavioral, psychological and political factors with influence on tax morale. A sample of 1,514 individual's from EVS - European Values Survey regarding to Portugal was used to study tax morale dimensions. We applied a factor and regression analysis procedures to assess

Manuscript received April 21, 2013; revised June 30, 2013.

C. Sá is with the Polytechnic Institute of Leiria, School of Technology and Management, Campus 2, Morro do Lena - Alto do Vieiro, 2411-901 Leiria, Portugal (e-mail: cristina.sa@ ipleiria.pt).

A. Martins is with the University of Coimbra, School of Economics, Av Dias da Silva, 165, 3004-512 Coimbra, Portugal (e-mail: amartins@fe.uc.pt).

C. Gomes is with the University of Coimbra, School of Economics, Av. Dias da Silva, 165, 3004-512 Coimbra, Portugal and with ISR, Operations Management Group, Pinhal de Marrocos - Polo II, 3030 Coimbra, Portugal (e-mail: cfgomes@fe.uc.pt). the significance of political democratic system, political participation, religiosity, individual satisfaction, trust in others and institutional trust as dimensions of tax morale, and also the significance of occupation status and income level.

\section{LITERATURE REVIEW}

Taxpayers exhibit a wide range of behaviors towards their tax obligations, justified for several reasons, ranging from an economic point of view to behavioral, political and psychological motivations. The consideration of moral feelings, like shame and guilt is relevant to provide a satisfactory explanation about taxpayer's compliance behavior [6]. Complying or not is also a function of individual's willingness and not only a function of deterrence factors [2].

Tax morale is the intrinsic motivation of individuals to pay taxes and a civic duty which can be crucial to explain the level of acceptance of tax burden [2], [6]. It can be conceptualized as a set of moral principles or values that individuals have regarding the payment of their taxes [7]. Among the range of tax morale definitions provided by the literature, it seems clear that moral rules and feelings, equity and the relation between taxpayers and government are important factors for an understanding of the concept. A better understanding of tax morale concept can be made in the light of the many factors that have been identified to shape it.

Tax morale is a multidimensional concept and requires an interdisciplinary approach [8]. Individuals satisfied with how democracy has evolved and with the way the country they live in is being governed, have higher levels of tax morale [8]. Opportunities for political participation contribute to "procedural goods of democracy" [9]. Moreover, knowing that citizens are discussing and monitoring its behavior provides government with an incentive to act more effectively. Such participation further contributes to more effective governance, by offering citizens the opportunity to speak out, and show their preferences. The more aware a government is of citizens preferences, the better its policies will reflect citizens' needs [10]. Church as an institution induces moral constraints in a community and influences people's behavior [11]. Many economists have made use of subjective questions on welfare (financial satisfaction), well-being, and health satisfaction, among others, to address a wide range of scientifically and politically relevant questions. Happiness and individual satisfaction were found to have a significant positive effect on taxpayers' tax morale in Asian countries and in Latin America [8], [12]. Trusting other citizens and political leaders are two contributing factors for people to pay taxes more willingly [13]. 
Experimental settings show that tax morale increases with individual perceptions of good governance [14]. Generally, it can be argued that positive actions by the state are intended to improve taxpayers' attitudes and commitment to the tax system, and thus enhance compliant behavior [3]. If the state acts trustworthily, taxpayers might be more willing to comply with taxes. On the other hand, perceived unfairness increases the incentive to act against the tax law, as it reduces psychological costs. In this context, if taxpayers trust the government and the state, their willingness to comply with their tax obligations will be higher [3]. National pride is used as used as a proxy to evaluate the degree of the taxpayer's identification with the state [8]. This feeling provides a basis for encouraging cooperative behavior. Thus, the greater the pride a person has in belonging to a country, the greater his/ her tax morale is [2]. A strong evidence that patriotism has a positive effect on tax morale was found for for Latin America, for Asia and for Russia [8], [12], [15]. We can conclude that the social context and institutional structure, in which the tax compliance occurs, influence the level of tax morale of each taxpayer.

Over the years, empirical research has systematically stressed the importance of socio-demographic variables in the understanding of tax morale [11], [16]. Empirical studies support a tendency for part time employees, housewives and retired taxpayers to have higher tax morale, compared to other taxpayers [3]. The effects of income on tax morale are difficult to assess theoretically. Greater income can contribute to an increase or a decrease on tax morale, depending on risk preferences, income tax rate progressivity, and opportunity costs of time spent on dealing with tax issues [7]. However there is a tendency for individuals with higher incomes to exhibit lower levels of tax morale [11]. The Methodology and Model

The research instrument utilized in this study was the EVS carried out in 2008 in Portugal. This instrument allows us to work with a representative set of, at least 1,000 individuals of Portugal. Representative multi-stage or stratified random samples of the adult population older than 17 years were drawn. The sample included individuals aged between 18 and 98 years old with an average of 53 years old. About fifty-four percent $(54.4 \%)$ of respondents are women and almost forty-one $(40.6 \%)$ are male. Most of the respondents are married $(60.0 \%)$ and around $18.0 \%$ have never been married or with registered partnership. There are individuals from all regions of Portugal, with emphasis for North (39.0\%), Center (28.34\%) and Lisbon (17.4\%). Around ninety-one (90.8\%) percent of respondents have up to (upper) secondary education. Almost sixty-eight percent $(67.90 \%)$ of the respondents earn less than $€ 18,000$ a year. However, a high percentage of the respondents $(48.0 \%)$ did not answer the question or did not new how much their annual income was. Regarding to employment status, $44.10 \%$ of the respondents are employed and $34.3 \%$ are retired or pensioned.

The first objective of the data analysis was to assess the dimensionality of the tax morale. The second objective was to study the influence of occupational status, income level and the identified dimensions on tax morale. Firstly, we used an exploratory factor analysis (EFA) to extract the underlying dimensions of tax morale. Sample adequacy for all variables was assessed by Kaiser-Meyer-Olkin test. The adequacy of factor analysis was measured with Bartlett test. Secondly, we used multiple regression analysis to explore the relationships among the tax morale dimensions revealed by factor analysis and between individual's occupation status and income level.

\section{THE METhOdOLOGY AND MODEL FACTOR ANALYSIS RESULTS}

\section{A. Factor Analysis Results}

Using the Kaiser-Meyer-Olkin test, sample adequacy for all variables was analyzed. A sample adequacy overall value of 0.713 was obtained. It represents a value considered acceptable for this type of analysis [17]. The adequacy of factor analysis was measured with Bartlett test. The values of Bartlett's test were $x 2=7618.568, d f=190$ and $p=1.000$, which confirmed the appropriateness of the factor analysis procedure as used. The principal component method, with a varimax rotation was used to extract relevant factors. The EFA results showed that all indicators with loadings greater than 0.56 in just one factor, and eigenvalues greater than 1 were considered (Guttman-Kaiser rule). The measure of sample adequacy (MSA) is greater than 0.62 for all variables. The seven-factor (tax morale, political participation, democratic political system, religiosity, individual satisfaction, trust in others and institutional trust) solution obtained explained 66.355 percent of the total variance.

\section{1) Factor one: Democratic political system}

A democratic political system offers citizens the possibility to express their preferences. Also, a more active role of the citizens helps them to better monitor and control politicians, and thus to reduce the asymmetry of information, which reduces the discretionary power of the government [12]. This factor includes the following variables:

- Level of agreement with political democratic system as the best political governance regime;

- Level of agreement with democracy as the best form of government.

\section{2) Factor two: Political participation}

Politically interested citizens will tend to associate and engage in discussion. Exchange of arguments and face-to-face interaction enhances group identification and give citizens the opportunity to identify others' preferences. As these preferences become visible, the moral costs of free-riding or behaving illegally increase, reducing the justification for corruption and tax evasion [18]. A higher political participation and interest is linked to an increase on levels of tax morale. This factor included the following variables:

- People's availability to sign petitions;

- People's availability to join boycotts;

- Presence in public manifestations.

\section{3) Factor three: Religiosity}

Religion can be seen as a proxy for characteristics like work ethics, tolerance and trust [19]. Every society has moral constraints, some of which are not formally laid down, but nevertheless influence citizens' behavior. Many of these standards are highly influenced by religious motives [20]. 
We explored religiosity influence on tax morale with four variables:

- Moral role of church on individuals' life;

- Frequency of attending religious services, not counting weddings, funerals and christenings;

- Level of confidence an individual has in the church;

- Importance of certain religious services, like funerals.

\section{4) Factor four: Individual satisfaction}

The level of happiness of an individual can influence economic decisions, including consumption, behavior at work, investment decisions and political behavior [21]. This factor included the following variables:

- Level of satisfaction with the job;

- Level of satisfaction with life;

- Level of control over life.

\section{5) Factor five: Trust in others}

People trust others based upon the belief that their fellow citizens are part of a moral community [21]. In fact, taxpayers are willing to pay their taxes conditionally. This factor included the following variables:

- Perception that the others try to be fair or try to take advantage of fellow citizens;

- Perception of the availability of people to help others.

6) Factor six: Institutional trust

A sustainable tax system is based on a fair tax system and responsive government, achieved with strong connection between tax payments and the supply of public goods [23]. Positive actions by the state are intended to improve taxpayers' attitudes and their commitment to the tax system and lead to compliant behavior [3]. This factor includes the following variables:

- Level of confidence an individual has in the government;

- Level of confidence an individual has in the parliament;

- Level of confidence an individual has in the judicial system.

\section{7) Factor seven: Tax morale}

Tax morale represents the individuals' willingness and the moral obligation to pay taxes or their belief in contributing to the society by paying taxes [8]. This factor includes the following variables:

- Level of justification to cheat on tax if one has the chance;
- Level of justification to avoiding a fare on public transport;

- Level of justification to paying cash for services to avoid taxes.

\section{B. Regression Results}

In the first part of the analysis, behavioral, psychological and political variables referred in the literature as having influence over tax morale were identified. Six variables resulted from the extracted factors (average of the measures), along with national pride were selected to investigate that influence, using the multiple regression analysis. Two qualitative variables were also included in the regression model, namely occupational status ( 1 - for part time employed, housewife and retired people; 0 - otherwise) and income level ( 1 - yearly income greater than $€ 12,000 ; 0-$ yearly income less than $€ 12,000$ ). For this purpose, the linear regression model used tax morale as dependent variable. The results show that only five of the seven identified variables and the two qualitative variables are significant (Table I), thus resulting in the following model:

$$
\begin{aligned}
& T M=1.434+0.413 P D+0.174 I S-0.074 T O-0.122 I T+ \\
& 0.255 P R-0.433 O C-0.162 I N
\end{aligned}
$$

where: TM - individual degree of tax morale (low values are associated with high motivation to comply with fiscal obligations, meaning high tax morale);

- PD - political democratic system;

- IS - individual satisfaction;

- TO - trust on others;

- IT - institutional trust;

- $\mathrm{PR}$ - proud in being a Portuguese citizen;

- OC - occupational status;

- IN - individual's yearly income;

Based on the regression results, Portuguese taxpayers' motivation to comply is mainly increased by the existence of democracy as a political regime, by individual satisfaction with life and by citizen's identification with Portugal as a country. The perception of respondents that other people have a fair behavior significantly increases citizen's intrinsic motivation to comply. We also found a negative statistically significant relation between institutional trust and tax morale. Although this result is not in line with literature review, we think that our result can be justified by the very low level of institutional trust stated by the respondents.

\begin{tabular}{|c|c|c|c|c|c|c|}
\hline & $R$ & $R^{2}$ & Adjusted $R^{2}$ & \multicolumn{3}{|c|}{ Standard error of the estimate } \\
\hline & 0.300 & 0.090 & 0.085 & \multicolumn{3}{|c|}{1.430} \\
\hline & $\begin{array}{c}\text { Unstandardized } \\
\text { coefficients } B\end{array}$ & standard error & $\begin{array}{c}\text { Standardized } \\
\text { coefficients Beta }\end{array}$ & $t$ & Sig. & $\begin{array}{c}\text { Variance } \\
\text { inflation factor }\end{array}$ \\
\hline Constant & 1.434 & .301 & & 4.763 & .000 & \\
\hline $\mathrm{Oc}$ & -.433 & .081 & -.144 & -5.368 & .000 & 1.181 \\
\hline In & -.162 & .085 & -.049 & -1.890 & .059 & 1.097 \\
\hline PD & .413 & .074 & .141 & 5.594 & .000 & 1.047 \\
\hline PP & -.087 & .064 & -.036 & -1.351 & .177 & 1.157 \\
\hline Rel & 0.047 & .045 & .027 & 1.022 & .307 & 1.119 \\
\hline IS & .174 & .029 & .154 & 5.594 & .000 & 1.120 \\
\hline TO & -.074 & .022 & -.085 & -3.303 & .001 & 1.090 \\
\hline IT & -.122 & .052 & -.061 & -2.326 & .020 & 1.131 \\
\hline PR & .255 & .063 & .105 & 4.406 & .000 & 1.118 \\
\hline
\end{tabular}

TABLE I: LINEAR REGRESSION RESULTS FOR TAX MORALE AS DEPENDENT VARIABLE 
In our estimation the variables controlling for occupational status and income are both statistically significant at the 0.01 and 0.1 respectively. Part time employed, housewives and retired taxpayers show higher levels of tax morale when compared to taxpayers with other occupational status, including employed and unemployed. Also, taxpayers with yearly income higher than $€ 12,000$ tend to present a high level of tax morale. Literature review suggests a positive or negative relation between income and tax morale, depending on several factors. From our point of view our significant negative relation can be explained by the existence of a high tax moral level stated by taxpayers (mean 2.09 and standard deviation 1.495).

\section{CONCLUSION}

A significant number of empirical studies about tax behavior explanation have been accumulated over the last 40 years. Results of statistical methods applied to survey data or to laboratory experiments, or to a combination of both, induced a significant advance in tax compliance understanding. Still, there are major gaps to be clarified [23]. Recent empirical literature about taxpayers' behavior and compliance evidence the considerations of behavioral and psychological variables, namely of tax morale to explain the existent levels of compliance. The intrinsic motivation to pay taxes can be the key to provide an explanation about taxpayer's behavior over the years and in different countries.

Using data from EVS regarding to Portugal, we first conducted a factor analysis to identify the dimensions underlying tax morale of Portuguese taxpayers. Secondly, we applied a regression analysis to study the influence of the identified dimensions and yearly income and occupation status on tax morale. Our results indicate that, in Portugal, individuals who support democracy as the best political regime, individual's satisfied with their lives, strongly identified with the country and with the conviction that others have a fair behavior tend to have a higher intrinsic motivation to comply. Also, we verify that part time employed, housewife and retired taxpayers have higher levels of tax morale in comparison with employed and unemployed taxpayers. And taxpayers with income levels higher than $€$ 12,000 state higher levels of tax morale.

Our results suggest that in Portugal tax morale is influenced by a multidisciplinary set of factors, namely political, psychological and behavioral factors. Tax authorities and politicians should use the results of studies of this nature to better focus their strategies and actions in order to increase compliance, reduce tax evasion and the underground economy.

\section{REFERENCES}

[1] R. Dell'Anno, "Tax evasion, tax morale and policy maker's effectiveness," Journal of Socio-Economics, vol. 38, pp. 988-997, 2009.

[2] B. Torgler, "Tax morale, rule-governed behavior and trust," Constitutional Political Economy, vol. 14, no. 2, pp. 119-140, 2003.

[3] B. Torgler, F. Schneider, and C. A. Schaltegger, "Local autonomy, tax morale, and the shadow economy," Public Choice, vol. 144, no. 1-2, pp. 293-321, 2009.
[4] S. Kim, "Does political intention affect tax evasion?" Journal of Policy Modeling, vol. 30, pp. 401-415, 2008.

[5] B. Erard and J. S. Feinstein, "The role of moral sentiments and audit perceptions in tax compliance," Public Finance, vol. 49, pp. 70-89, 1994.

[6] J. M. Vazquez and B. Torgler, "The evolution of tax morale in modern Spain," Journal of Economic Issues, vol. 43, no. 1, pp. 1-28, 2009.

[7] J. Alm and B. Torgler, "Culture differences and tax morale in the United States and in Europe," Journal of Economic Psychology, vol. 27, no. 2, pp. 224-246, 2006

[8] B. Torgler, "Tax morale in Latin America," Public Choice, vol. 122, no. $1-2$, pp. 133-157, 2005.

[9] R. E. Lane, "Procedural goods in a democracy," Social Justice Research, vol. 2, pp. 177-192, 1988.

[10] C. Boix, and D. Posner, "Social capital: explaining its origins and effects on government performance," British Journal of Political Science, vol. 28, no. 4, pp. 686-695, 1998.

[11] B. Torgler and F. Schneider, "Attitudes towards paying taxes in Austria: An empirical analysis," Empirica, vol. 32, pp. 231-250, 2005.

[12] B. Torgler, "Tax morale Asia: An alternative tax policy strategy? Evidence from a controlled field experiment in Switzerland," Economics of Governance, vol. 5, pp. 235-253, 2004.

[13] J. T. Scholz and M. Lubell, "Adaptive political attitudes: duty, trust and fear as monitors of tax policy," American Journal of Political Science, vol. 42, pp. 398-417, 1998

[14] R. G. Cummings, J. M. Vazquez, M. McKee, and B. Torgler, "Tax morale affects tax compliance: evidence from surveys and an artefactual field experiment," Journal of Economic Behaviour and Organization, vol. 70, no. 3, pp. 447-457, 2009.

[15] J. Alm, J. M. Vazquez, and B. Torgler, "Russian attitudes toward paying taxes - before, during, and after the transition," International Journal of Social Economics, vol. 33, pp. 832-857, 2006.

[16] G. Barone and S. Mocetti, "Tax morale and public spending inefficiency," International Tax and Public Finance, vol. 18, pp. 724-749, 2011.

[17] Multivariate Data Analysis (7th ed.), Prentice Hall, New Jersey, 2009.

[18] B. Torgler and N. Valev, "Gender and public attitudes toward corruption and tax evasion," Contemporary Economic Policy, vol. 28, no. 4 , pp. $554-568,2010$

[19] B. Torgler, "The importance of faith: Tax morale and religiosity," Journal of Economic Behaviour \& Organization, vol. 61, no. 1, pp. 81-109, 2006.

[20] B. S. Frey and A. Stutzer, "What can economists learn from happiness research?" Journal of Economic Literature, vol. 40, no. 2, pp. 402-435, 2002.

[21] B. S. Frey and B. Torgler, "Tax morale and conditional cooperation," Journal of Comparative Economics, vol. 35, no. 1, pp. 136-159, 2007.

[22] R. Bird, J. M. Vazquez, and B. Torgler, "Societal institutions and tax effort in developing countries," in The Challenges of Tax Reform in the Global Economy, J. Alm, J. Martinez-Vazquez, and M. Rider (Eds.), Springer, New York, 2006, pp. 283-338.

[23] J. Alm, "Measuring, explaining, and controlling tax evasion: lessons from theory, experiments, and field studies," Public Finance, vol. 19, pp. 54-77, 2012.

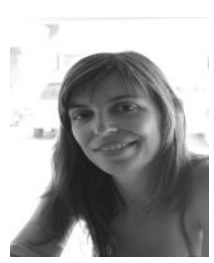

Cristina Sá is a portuguese manager. She holds a degree in Management (University of Coimbra, Portugal, 2002) and a MBA (University of Coimbra, Portugal, 2008). She is a lecture at School of Technology and Management of Polytechnic Institute of Leiria and a PhD student in University of Coimbra. She teaches Taxation. She is a consultant with Portuguese entities in taxation. She was financial manager of a Portuguese company for about ten years. She has published in proceedings of professional meetings and Portuguese taxation publications. Her main research interests are taxpayer behavior and tax morale.

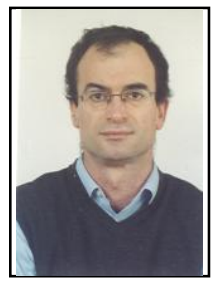

António Martins is a portuguese economist. He holds a BSc Economics (University of Coimbra, Portugal, 1985) and a Phd in Management (University of Coimbra, Portugal, 1999). He is an Assistant professor, School of Economics, Coimbra University. He teaches Taxation. António Martins has been publishing in the areas of Corporate Taxation/Financial Accounting. His work has appeared in publications such as: Journal of Applied Accounting Research; European Taxation; 
International Journal of Law and Management and Management of Environmental Quality: an International Journal. He is a tax consultant with Portuguese and foreign entities.

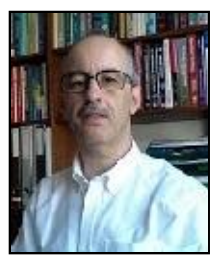

Carlos F. Gomes is an assistant professor with aggregation in Operations Management at the School of Economics - University of Coimbra and researcher at the Operations Management Group - ISR Coimbra, Portugal. He received a $\mathrm{PhD}$ in Industrial Management, an MSc in Industrial Management, a postgraduate certificate of Advanced Studies in Industrial Quality and International Business, and a BS in Electrical
Engineering, all from the University of Coimbra. Currently, he is Coordinator of the Undergraduate Program in Management, and Co-coordinator of PhD Program in Business Management. His main research interests are performance management, operations strategy, and improvement of manufacturing and service systems. He has published in proceedings of professional meetings and in several refereed journals such as International Journal of Production \& Operations Management, Service Industries Journal, and Project Management Journal. 